\title{
The Effect of Explicit Teaching and Implicit Learning of Concept and Generalization Structure on The Acquisition of Explicit Knowledge of Concept and Generalization Structure
}

\section{Mükerrem AKBULUT TAŞ ${ }^{\mathrm{a}^{*}}$, Mahinur KARATAŞ COŞKUN ${ }^{\mathrm{a}}$}

\begin{tabular}{|c|c|}
\hline Article Info & Abstract \\
\hline DOI: 10.14812/cufej.2014.001 & \multirow{6}{*}{$\begin{array}{l}\text { The general purpose of this study is to investigate the effect of explicit teaching and } \\
\text { implicit learning of the concept and generalization structure on the acquisition of } \\
\text { explicit knowledge regarding concept and generalization structure in the Learning- } \\
\text { Teaching Theories and Approaches course instructed in the non-thesis master's } \\
\text { program of the Secondary Education Teaching Department in Educational Sciences. } \\
\text { The study was conducted as a pre-test/post-test quasi-experimental design with } 97 \\
\text { students in two experimental and two control groups. The data was analysed using } \\
\text { means, standard deviations, adjusted means, chi-square analysis, one-way Anova, } \\
\text { covariance (Ancova) and Bonferroni analysis. Results indicate that when compared to } \\
\text { implicit learning, the explicit teaching provided to the first experimental group was } \\
\text { found to be effective in the acquisition of explicit knowledge regarding concept and } \\
\text { generalization structure, increasing the perceived confidence rating about the } \\
\text { accuracy of responses, and providing successful learning. However, it is recommended } \\
\text { that students should be exposed to a wide number of correct examples and to } \\
\text { frequently have applied the practices with a view to making the gained explicit } \\
\text { knowledge usable in a specific context. }\end{array}$} \\
\hline Article history: & \\
\hline Received 28 February 2013 & \\
\hline Revised $\quad 11$ November 2013 & \\
\hline Accepted $\quad 02$ February 2014 & \\
\hline $\begin{array}{l}\text { Keywords: } \\
\text { Explicit teaching, } \\
\text { Implicit learning, } \\
\text { Explicit knowledge, } \\
\text { Concept structure, } \\
\text { Generalization structure. }\end{array}$ & \\
\hline
\end{tabular}

\section{Introduction}

People gain various knowledge and skills in the learning process. However, whether this process is always in the control of individuals, or whether it is conscious, has been subject to much debate (Berry \& Broadbent, 1988; Overskeid, 1995; Shanks \& St. John, 1994).

As stated by Shanks and St. John (1994), the main problems faced by researchers in the studies on learning include whether there is more than one learning mechanism, whether learning phenomena as a whole can be included in one mechanism, and whether it is possible to accept the presence of learning systems that are different, independent of each other. Learners' being active in their learning process without awareness has not been researched in learning studies. When this process happens unconsciously, it is called implicit learning (Underwood \& Bright, 1996) (in Davou, 2002). Implicit learning was first mentioned by Reber (1967). Reber (1993) asked people to memorize a set of letters which was organized according to a complex set of rules (artificial grammar rules), and was not known by the participants. The participants memorized the sets, and a few minutes later they were told the sets had rules. However, these rules were not explained. Then, the participants were asked to classify new sets of letters that matched and did not match the rules. They could manage correct classification at a ratio of 60-70\%, but could not explain the rules that helped their classification. Reber (1993), by the help of the evidence obtained from the typical artificial grammar learning studies, defined implicit learning as "acquisition of knowledge that takes place largely independently of conscious attempts to

*Corresponding author: mukerremtas@gmail.com 
learn, and largely in the absence of explicit knowledge about what was acquired". According to Reber, implicit learning is a passive process which is not accompanied by learners' awareness and in which individuals unconsciously use automatic abstraction. Frensch (1998) argues that implicit learning is a single concept, but it has more than one definition. According to Frensch, implicit learning is an unconscious, spontaneous, and automatic acquisition of knowledge and recalling process. Ellis (2005) defines implicit learning as acquisition of knowledge about the underlying structure of a complex stimulus environment by a process which takes place naturally, simply, and without conscious process. Explicit learning is a conscious process where the individual makes and tests a hypothesis in a search for structure (Ellis, 2005). In this process, concepts, rules, principles and patterns are directly presented to learners, and learners are asked to search this structure actively (Gasparini, 2004). In the implicit learning process, individuals can acquire complex and abstract relations by exploring the structures and rules underlying the task, without using conscious processes. In implicit learning tasks, structures or rules repeat in a regular and invariant way, and the person can abstract a complex structure by being exposed to this recurrent structure (Mathews et al., 1989; Reber, 1993). Review of the related literature shows that implicit learning is defined as unconscious, intuitional, automatic and unconscious learning processes, while explicit learning is defined as conscious (intentional) learning processes, in which learners are aware (Ellis, 2005; Frensch, 1998; Gasparini, 2004; Reber, 1993; Shanks, 2005).

Attainment of knowledge can be achieved through both implicit and explicit learning (Antony \& Santhanam, 2007). The knowledge acquired in the implicit learning process is implicit knowledge while the knowledge acquired in the explicit learning process is explicit, declarative knowledge. According to Squire (1995), implicit learning brings in and uses nondeclarative knowledge. Therefore, assessment of implicit knowledge requires indirect practice of the knowledge acquired, rather than verbal expressions (in Kirkhart, 2001). Mathews, Roussel, Cochran, Cook and Dunaway (2000) point that implicit knowledge is gained by means of experiences; implicit, experiential knowledge is dominant in human performance of complex tasks; and the implicit, experiential knowledge acquired in real life is combined with conceptual or reflective knowledge in the related subject area. According to Mathews et al. (2000), implicit, experiential learning is acquired through being exposed to good examples and cases, while reflective knowledge is acquired through teaching or books, and through conscious thoughts about the concepts in the subject area.

One of the independent variables investigated in implicit learning research is explicit teaching. Shuell (1996) defines explicit teaching as a teaching strategy in which teachers present the knowledge to be learned and direct the learning process explicitly (in Eggen \& Kauchak, 2007). Studies on explicit teaching approach which are reconstructed in light of the modern education understanding have investigated issues such as strategy teaching (e.g. learning and thinking strategies), instruction of knowledge such as concepts, principles, laws, theories, and cases, instruction of higher order thinking skills, education of children with learning difficulties, scaffolding, and review of previous knowledge (Carnine, 1994; Eggen \& Kauchak, 2007; Magliaro, Lockee, \& Burton, 2005; McCleery, 2000).

\section{Problem}

Implicit learning literature is generally based on laboratory studies. However, implicit learning in real life is a fundamental process which involves various areas such as learning mother-tongue language and second-language, category elaboration, concept learning, reading-writing acquisition, and acquisition of knowledge about the physical world and social skills (Pacton, Perruchet, Fayol, \& Cleeremans, 2001). Pacton et al. (2001) emphasize that results obtained from laboratory studies in relation to a learning type that is effective in such a large area cannot be generalized to behavioural situations in real life, and these important findings in particular are ignored by cognitivists. This deficiency results from the inadequate number of studies that investigate the relationship between implicit learning and real-life learning. Because studies of implicit learning are generally conducted in laboratory environments, it is hard to apply the findings of these studies in real-life learning environments. Moreover, implicit rule 
abstraction was found to fail in studies carried out real-life environments. Even though it can be observed, implicit learning does not create any significant differences; explicit teaching is reported to be more effective (Robinson, 1997; Sætrevik, Reber, \& Sannum, 2006). In other words, studies carried out in real-life education environments have not provided strong evidence in relation to implicit learning. On the other hand, Reber (1993) proposed implicit learning as a disposition for Dewey's experiential education programs. Thus, school programs can be changed on the basis of the results obtained from implicit learning studies so that students could be exposed to knowledge and structures in a specific subject area. In this way, certain instruction rules and formulas can be learned using less energy and time. Reber states that explicit teaching is not effective in learning the rules underlying the structure of complex environment/stimulus, and we usually learn these kinds of patterns by experiencing them on our own. However, Reber also states that he does not recommend any systems which will fully develop the education system because implicit learning studies have not provided any evidence in this direction. There are no clear guides on how implicit learning can be included in the curriculum, or in what specific subject areas it can beneficial. In this regard, how exactly implicit learning and implicit knowledge can be beneficial in teaching-learning practices may be seen to be an important problem. Sætrevik et al. (2006) point that techniques that form the basis for implicit learning studies have begun to take a more important place in the curriculum day by day; however, more empirical evaluations are needed in order to prevent inefficient and insufficient teaching tools from getting into the programs.

This study has investigated the effects of explicit teaching and implicit learning of concept and generalization structure on the attainment of explicit knowledge. Since implicit learning studies investigate the features of concepts and rules (principles) as well as the frequency of these features as patterns that demonstrate regular systems (Frick \& Lee, 1995; Mathews, Buss, Chinn, \& Stanley, 1988; Ziori \& Dienes, 2006, 2008) this study also has chosen the concept and generalization structure which forms a meaningful pattern. The concept structure used in the study refers to the content component of the concept. Components which form a concept are concept name, concept definition, critical attributes of the concept, variable attributes, concept hierarchy, and concept examples and non-examples. Generalization structure composes the content components of the generalization. Components that form a generalization include generalization name, statements of generalization as proposition, concepts that comprise principles, interrelationships (causal) among the concepts, examples and nonexamples of the generalization (Merrill, 1983).

Studies on implicit learning are quite limited in number in Turkey. Some of these studies have investigated implicit memory (Amado, 1996; Tatar, 1998; Tavat, 1991). The studies which are directly or indirectly related to implicit learning are usually in the foreign language learning domain (Debbağ-Ergin, 2008; Karadağlı, 2009; Özcan-Bayram, 2009; Türk, 2007). Thus, given that the present study has been conducted in a classroom environment, the findings are thought to shed light to and become a reference for the issue of applicability of implicit learning activities into real classroom environments. It is generally indicated that education usually emphasizes explicit learning and explicit knowledge, and evaluations generally focus on what students can say rather than what they can do, but implicit, intuitive knowledge and implicit learning are ignored (Gasparini, 2004; Reber, 1993). However, beginning from early childhood, implicit learning and implicit knowledge are attained in every field and context of life. Implicit knowledge is the knowledge that forms the basis for our cognitive background, interpretive point of view, paradigms, mental models and beliefs, namely knowledge that is guaranteed (Neuweg, 2004). This knowledge improves with experience, repetition and practice. This study may call attention to the necessity of giving importance to implicit knowledge as much as explicit knowledge in learning and teaching activities. In addition, considering the fact that inefficient or inadequate implicit learning in teaching-learning processes, as well as in school life in general, affect students' mental processes and actions in a negative way, this study is of great importance in terms of the topic it addresses. Implicit learning activities were based on the teaching content of "Concepts and Principles of Behaviourist Learning Theory". In line with the above-mentioned explanations and reasons, the statement of the problem in the present study is "what is the effect of explicit teaching and implicit 
learning of concept and generalization structure on the acquisition of explicit knowledge regarding concept and generalization structure?"

\section{Purpose of The Study}

The general purpose of this study is to investigate the effect of explicit teaching and implicit learning of concept and generalization structure on the acquisition of explicit knowledge regarding concept and generalization structure in the "Learning-Teaching Theories and Approaches" course, instructed in the non-thesis master's program of the Secondary Education Teaching Department in Educational Sciences.

In line with this general purpose, the study was guided by the following sub-objectives:

1. When the pre-test short-answer test on concept-generalization structure (CGSSAT) scores of the Experimental Group-1, Experimental Group-2, Control Group-1, and Control Group-2 are controlled, are there any significant differences between the post-test total achievement scores in favour of the experimental group?

2. CGSSAT scores of the Experimental Group-1, Experimental Group-2, Control Group-1, and Control Group-2;

2a. When the pre-test confidence rating mean difference scores are controlled, are there any significant differences between the post-test confidence level mean difference scores in favour of the experimental groups?

$2 \mathrm{~b}$. When the pre-test correct response confidence rating mean scores are controlled, are there any significant differences between the post-test correct response confidence rating mean scores in favour of the experimental groups?

3. When the pre-test the multiple choice test on concept-generalization structure (CGSMCT) scores of the Experimental Group-1, Experimental Group-2, Control Group-1, and Control Group-2 are controlled, are there any significant differences between the post-test total achievement scores in favour of the experimental group?

4. CGSMCT scores of the Experimental Group-1, Experimental Group-2, Control Group-1 and Control Group-2;

4a. When the pre-test confidence rating mean difference scores are controlled, are there any significant differences between the post-test confidence level mean difference scores in favour of the experimental groups?

4b. When the pre-test correct response confidence rating mean scores are controlled, are there any significant differences between the post-test correct response confidence rating mean scores in favour of the experimental groups?

\section{Method}

This study was conducted as pretest-posttest quasi-experimental design which is frequently used in educational research. Quasi-experimental designs do not require random assignment, and thus they can be used in many cases when the real experimental design requirements are insufficient or cannot be met (Cohen, Manion \& Morrison, 2007; Hovardaoğlu, 2007; Karasar, 1995, p.99). The present study made use of quasi-experimental design because it involved a number of variables (interest and attitudes concerning the curriculum, gender, socio-economic level, knowledge of the domain, experience in the domain, etc.) to be considered while forming the experimental and control groups, and because the participants could not be randomly assigned to the groups. If it is not possible to equalize the groups in quasi-experimental studies, researchers are recommended to obtain similar groups as far as possible (Cohen et al., 2007; Karasar, 1995). Special attention was taken to form the groups with the students in the math field and to create the experimental group from students in the same professional domain. There are nine groups in the non-thesis master's program. Since three of these groups are from the nonmath field, and one group is mixed (chemistry-physics), they were not included in the study. The four groups to be included in the study were chosen by casting among the remaining five groups. Once one 
of the maths groups was chosen for the experimental group, the other maths group was assigned as the other experimental group, with a view to meeting the requirements of the experimental design. In this regard, the present study formed two experimental and two control groups.

The independent variable of the study is the type of teaching (explicit teaching or implicit learning). and the dependent variables are acquisition of explicit knowledge about concept and generalization structure; controlled variables are pre-test scores of the groups. Table 1 presents the research model figure.

Table 1.

Presenting Research Model Figure

\begin{tabular}{llllll}
\hline Groups & Pre-tests & $\begin{array}{l}\text { Experimental } \\
\text { treatment -I }\end{array}$ & Post-tests & $\begin{array}{l}\text { Experimental } \\
\text { treatment -II }\end{array}$ & Post-tests \\
\hline $\mathrm{G}_{1}$ & $\mathrm{O}_{1.1}+\mathrm{O}_{2.1}$ & $\mathrm{X}_{1}$ & $\mathrm{O}_{1.2}+\mathrm{O}_{2.2}$ & $\mathrm{X}_{2}$ & $\mathrm{O}_{1.3}+\mathrm{O}_{2.3}$ \\
$\mathrm{G}_{2}$ & $\mathrm{O}_{3.1}+\mathrm{O}_{4.1}$ & & & $\mathrm{X}_{2}$ & $\mathrm{O}_{3.3}+\mathrm{O}_{4.3}$ \\
$\mathrm{G}_{3}$ & $\mathrm{O}_{5.1}+\mathrm{O}_{6.1}$ & & & $\mathrm{O}_{5.3}+\mathrm{O}_{6.3}$ \\
$\mathrm{G}_{4}$ & $\mathrm{O}_{7.1}+\mathrm{O}_{8.1}$ & & & & $\mathrm{O}_{7.3}+\mathrm{O}_{8.3}$ \\
\hline
\end{tabular}

Symbols presented in Table 1 are as follows,

$\mathrm{G}_{1}$ : Experimental Group-1. in which explicit teaching of concept and generalization structure, as well as the fundamental concepts and principles of behaviourist learning theory, are learned.

$\mathrm{G}_{2}$ : Experimental Group-2, in which concept and generalization structure is learned implicitly in the context of behaviourist learning theory.

$\mathrm{G}_{3}$ : Control Group-1, in which basic concepts and principles of behaviourist learning theory are taught by another instructor.

$\mathrm{G}_{4}$ : Control Group-2, in which basic concepts and principles of behaviourist learning theory are taught by another instructor.

$\mathrm{X}_{1}$ : Experimental treatment in which concept and generalization structure is taught explicitly.

$X_{2}$ : Experimental treatment in which concept and generalization structure is taught implicitly, in the context of basic concepts and principles of the behaviourist learning theory.

$\mathrm{O}_{1.1}-\mathrm{O}_{3.1}-\mathrm{O}_{5.1}-\mathrm{O}_{7.1} \quad$ : Short-answer pre-test on concept and generalization structure

$\mathrm{O}_{2.1}-\mathrm{O}_{4.1}-\mathrm{O}_{6.1}-\mathrm{O}_{8.1} \quad$ : Multiple-choice pre-test on concept and generalization structure

$\mathrm{O}_{1.2}$

:Short-answer post-test on concept and generalization structure administered in Experimental Group-1

$\mathrm{O}_{2.2}$ :Multiple-choice post-test on concept and generalization structure administered in Experimental Group-1

$\mathrm{O}_{1.3}-\mathrm{O}_{3.3}-\mathrm{O}_{5.3}-\mathrm{O}_{7.3} \quad$ : Short-answer post-test on concept and generalization structure.

$\mathrm{O}_{2.3}-\mathrm{O}_{4.3}-\mathrm{O}_{6.3}-\mathrm{O}_{8.3} \quad$ : Multiple-choice post-test on concept and generalization structure.

\section{Participants}

The population of the study consisted of 201 students enrolled in the Mathematics, Biology, and Physics departments of the non-thesis master's program in the Secondary Education Teaching Department at the Çukurova University of during the 2008-2009 academic year. Those who did not take pre-tests, post-tests, and transfer and retention tests for various reasons, those who did not complete the tests according to instructions, and those who were not present for the entire treatment process in the experimental group were not included in the study. The participants of the study were 97 students: 24 students in Experimental Group-1, 29 students in Experimental Group-2, 23 students in the Control Group-1, and 21 students in the Control Group-2.

In the first experimental group, $25 \%$ of the students were male (6) and $75 \%$ were female (19); in the second experimental group $24 \%$ of the students were male (7) and $76 \%$ were female (22); in the first 
control group $13 \%$ (3) of the students were male and $87 \%$ of them were female (20); and in the second control group, $48 \%(10)$ of the students were female and $52 \%$ were male (11). Chi-square analysis results of the gender variable show that there was no significant difference between the experimental and control groups in terms of gender $\left(\chi_{(3)}^{2}=7.002, p>.05\right)$; and the groups do not demonstrate any difference in terms of gender distribution. The average age of the participants in the experimental ( $\overline{\mathrm{X}}=$ 24.1) and control groups $(K-1: \bar{X}=25.4 ; K-2: \bar{X}=24.5)$ were close to each other.

Table 2 and Table 3 present the results of one-way variance analysis, which was performed with a view to identify the presence of significant differences in terms of CGSSAT, CGSMCT pre-test and CRS pre-test, which were all used as data collection tools in the experimental and control groups.

Table 2.

One-way ANOVA Results Pre-test Total Achievement Scores, Confidence Rating Mean Difference, and Correct Response Confidence Rating for CGSSAT in Experimental and Control Groups.

\begin{tabular}{|c|c|c|c|c|c|c|c|}
\hline \multirow[t]{2}{*}{ Groups } & $\begin{array}{l}\text { E-1 } \\
(n: 24) \\
\end{array}$ & $\begin{array}{l}\text { E-2 } \\
(n: 29)\end{array}$ & $\begin{array}{l}\text { C-1 } \\
(n: 23)\end{array}$ & $\begin{array}{l}\text { C-2 } \\
(n: 21) \\
\end{array}$ & $F$ & $p$ & \multirow[t]{2}{*}{$\begin{array}{l}\text { Significant } \\
\text { differences }\end{array}$} \\
\hline & $\bar{X}$ & $\bar{X}$ & $\bar{X}$ & $\bar{X}$ & & & \\
\hline $\begin{array}{l}\text { Total } \\
\text { Achievement } \\
\text { Scores }\end{array}$ & 4.96 & 6.20 & 4.35 & 3.71 & 2.892 & .040 & $\mathrm{D}_{2}>\mathrm{K}_{1}-\mathrm{K}_{2}$ \\
\hline $\begin{array}{l}\text { Confidence Rating } \\
\text { Mean Difference }\end{array}$ & 4.02 & 4.13 & 2.82 & 9.05 & 0.852 & .469 & \\
\hline $\begin{array}{l}\text { Correct Response } \\
\text { Confidence Rating }\end{array}$ & 65.67 & 63.09 & 64.35 & 74.48 & 4.904 & .003 & $\mathrm{~K}_{2}>\mathrm{D}_{1}-\mathrm{D}_{2}-\mathrm{K}_{1}$ \\
\hline
\end{tabular}

Table 2 shows that there is a significant difference between the experimental and control groups in terms of their CGSSAT pre-test total achievement scores $F(3-93)=2.892, p<.05$. LSD test results indicate that the difference is in favour of the second experimental group. No significant difference was found between the pre-test confidence rating mean difference scores of the groups $F(3-93)=0.852, p>05$. CGSSAT pre-test correct response confidence rating mean scores demonstrate significant differences $F(3-93)=4.904, p<.05$ between the experimental and control groups. LSD test results indicate that the difference is in favour of the second control group.

Table 3.

One-way ANOVA Results Pre-test Total Achievement Scores, Confidence Rating Mean Difference, and Correct Response Confidence Rating for CGSMCT in Experimental and Control Groups.

\begin{tabular}{|c|c|c|c|c|c|c|}
\hline \multirow[t]{2}{*}{ Groups } & $\mathrm{E}-1(n: 24)$ & $\mathrm{E}-2(n: 29)$ & $C-1(n: 23)$ & C-2 (n:21) & \multirow[t]{2}{*}{$F$} & \multirow[t]{2}{*}{$p$} \\
\hline & $\overline{\mathrm{X}}$ & $\overline{\mathrm{X}}$ & $\overline{\mathrm{X}}$ & $\bar{X}$ & & \\
\hline Total Achievement Scores & 15.46 & 14.86 & 13.87 & 12.52 & 2.122 & .103 \\
\hline $\begin{array}{l}\text { Confidence Rating Mean } \\
\text { Difference }\end{array}$ & 5.13 & 2.91 & 3.34 & 2.94 & 0.812 & .491 \\
\hline $\begin{array}{l}\text { Correct Response } \\
\text { Confidence Rating }\end{array}$ & 80.96 & 75.75 & 77.75 & 76.55 & 1.393 & .250 \\
\hline
\end{tabular}

As seen in Table 3, there are no significant differences between the experimental and control groups in terms of CGSMCT pre-test total achievement scores $\mathrm{F}(3-93)=2.122, \mathrm{p}>.05$, pre-test confidence rating mean difference scores $F(3-93)=0.812, p>.05$, and pre-test correct response confidence rating mean scores $F(3-93)=1.393, p>.05$. These findings suggest that experimental and control groups show similarity in terms of their explicit knowledge of concept and generalization structure. 


\section{Data Collection Instruments}

Data collection instruments used in the study are CGSSAT, CGSMCT, and the Confidence Rating Scale (CRS) recommended by Ziori and Dienes $(2006,2008)$ to be used in identifying students' confidence rating in the responses they give. More information on the data collection instruments is as follows:

\section{Concept and Generalization Structure Short-Answer Test (CGSSAT) and Concept and Generalization Structure Multiple Choice Test (CGSMCT)}

Tests on concept and generalization structure are formed with the questions related to the content components of concept and generalization. One short-answer and one multiple choice test, which include parallel questions, were developed in relation to concept and generalization structure. A shortanswer test was prepared as fill-in-the-blanks form. The purpose of preparing both short-answer and multiple choice tests on the same topic is that short-answer tests require more explicit knowledge. Short-answer questions require respondents to think about the knowledge in their mind and recall it. On the other hand, multiple choice questions require distinguishing between the given choices, and finding the correct one (Clariana \& Lee, 2001; Kang, McDermott, \& Roediger, 2007).

Short-answer tests are recalling tests; and it is not too possible to write the correct answer if one does not have explicit knowledge on the topic. Multiple choice questions are recognition tests and the correct answer is chosen among other choices. Respondents may reach the correct answer intuitively, or by guessing, even they do not have explicit knowledge on the issue. Although both tests require recalling explicit knowledge, cognitive processes with respect to recalling information and source of errors are different for these two tests (Clariana, 2003; Clariana \& Lee, 2001). Based on this information, the present study makes use of both short-answer and multiple choice tests as objective tests, with a view to assessing the participants' explicit knowledge in a more reliable way.

CGSSAT and CGSMCT include questions regarding the content components of concepts such as "concept name", "concept definition", "critical attributes of the concept", "variable attributes of the concept", "concept hierarchy", and "concept examples and non-examples". As for the content components of generalization, the questions are related to "generalization name", "statement of the generalization in form of proposition", "concepts in generalization", "interrelationships among concepts (causal relationships)", and "examples and non-examples of generalization". CGSSAT and CGSMCT, which were developed benefitting from the theoretical structure, were presented to four experts in the domain with the Expert Opinion Form (EOF) and investigated in terms of their content validity. The questions were revised in light of the recommendations and revisions suggested by the experts. The tests, which were designed as $\mathrm{A}$ and $\mathrm{B}$ forms and with equivalent questions, were piloted; and then item and test analyses were conducted on the test scores.

Item and test analyses of the CGSSAT used in the study was performed on the test scores of 119 students. Results show that the mean score of the 38-item test is ( $\bar{X}=17.46)$, median is 18.00 , and mode is 5 . Average difficulty of the test is .46; KR-20 value is .92. The range of values for the discrimination index was from .30 to .66. Item and test analysis of the CGSMCT were conducted on the test scores of 125 students. Results show that the mean score of the 33-item test is $(\bar{X}=18.52)$, median is 17.00 , and mode is 5 . Average difficulty of the test is .56; KR-20 value is .88 . The range of values for the discrimination index was from .25 to .62. For the CGSSAT, the highest score that can be obtained is 38 and the lowest score is 1 . For the CGSMCT, the highest score that can be obtained is 33 and the lowest score is 1 . 


\section{Confidence Rating Scale (CRS)}

Various assessment techniques are recommended for the assessment of awareness in implicit learning studies (Cleeremans, Destrebecqz, \& Boyer, 1998). Some examples include verbal reports, forced-choice tests (e.g. recognition tests), or objective and subjective tests (e.g. confidence judgment scale). This study made use of the Confidence Rating Scale (CRS) with a view to assessing explicit knowledge. CRS enables respondents to express perceived confidence regarding their performance in a task, or to specify the confidence they have when they are giving the right response (Sandberg, Timmermans, Overgaard, \& Cleeremans, 2010). In CRS, the participants are asked to rate their performance directly, and to indicate their confidence within the shortest time limit (e.g.7 seconds).

Dienes, Altmann, Kwan and Goode (1995) proposed two possible criteria with a view to demonstrating lack of explicit and conscious knowledge or acquisition of unconscious knowledge: guessing criterion and zero-correlation criterion (in Dienes \& Altmann, 1997). Guessing criterion is used with a view to evaluating whether the participants give the right classification decision rather than a wrong one, by believing when they have no confidence in their knowledge. When people only intuitively believe that their response is correct, they answer questions by guessing (Destrebecqz \& Peigneux, 2005; Ziori \& Dienes, 2006, 2008). Guessing criterion can be obtained by calculating the correct response percentages only accompanied by a confidence rating of $50 \%$. In other words, the analysed responses are those having a confidence rating of $50 \%$. The respondents who do not make any guesses are not included in the analysis (Ziori \& Dienes, 2006, 2008). No analysis with guessing criterion could be conducted in the present study because none of the groups had a large enough number of students who gave correct responses with $50 \%$ confidence rating. Evaluation of explicit knowledge was performed using only zero-correlation criterion. Zero-correlation criterion refers to low or no correlation between confidence ratings and correct responses. Zero-correlation criterion is the measurement of the relationship between confidence rating and correct response (confidence-accuracy relationship). If participants have attained explicit knowledge, they certainly have high confidence for the right decision (response) and low confidence for the wrong decision (response). If they are not aware of explicit knowledge, their high and low confidence scores are distributed randomly according to correct and wrong responses. Respondents have more confidence when they are giving correct responses than when they are giving wrong responses.

Confidence rating scale and zero-correlation criterion were used by getting information from Ziori and Dienes. In their various studies, Ziori and Dienes $(2006,2008)$ used a confidence rating scale that ranged from $50 \%$ to $100 \%$, with a view to conducting guessing criterion and zero-correlation criterion. In this scale, $50 \%$ indicates that the responses were given totally by guessing, and $100 \%$ means that participants are totally sure about the accuracy of the responses they give. If respondents choose 100 or values close to 100, it means that they are sure about their response and gave it knowingly. However, if they choose $50 \%$ or values close to it, it means that they give the response by guessing, and they are not sure about its accuracy. The participants were allowed to choose any value that is between these values. CRS was used as follows in the present study;

$50 \ldots . \ldots 55 \ldots \ldots 60 \ldots 65 \ldots \ldots . \ldots 70 \ldots . \ldots 75 \ldots \ldots 80 \ldots \ldots 85 \ldots . \ldots 90 \ldots 95 \ldots 100$

In this scale; $100 \%$ refers to "I am totally sure that my response is correct and I am very confident about its accuracy". 50 \% refers to "I gave the response totally by guessing, and I am not confident about its accuracy".

The present study obtained two score types which were developed benefitting from the zerocorrelation criterion, with a view to measuring explicit knowledge. The first one is the confidence rating difference score, which was obtained by identifying the difference between the mean score for the confidence rating scale for correct responses and the mean score for the confidence rating scale for 
incorrect responses. Confidence level mean scores obtained both negative and positive values because the participants chose scores indicating high confidence levels not only for the correct answers but also for the incorrect answers.

Confidence rating mean difference score = Mean score confidence rating for correct responses Meanscore confidence rating for incorrect responses

The second one is the correct response confidence rating score which was obtained by identifying the perceived confidence rating mean scores for only correct responses. CRS appeared under each question in the tests. The participants were asked to choose one of the numerical values right after they respond to the question, and if the value they want to choose is not present in the scale, they were asked to write down a value on their own.

\section{Data Collection}

The following procedures were conducted with a view to finding answers to the research questions:

1. The study was carried out in the "Learning-Instruction Theories and Approaches" course taught in the mathematics, biology, and physics departments in the master's program of the Programme in Secondary Education Subject Areas, Education Faculty at the University of Çukurova, during the 2008-2009 academic year.

2. Before the treatment, all the groups were first administered CGSSAT and then CGSMCT as pretests. The researcher explained the instructions on how to complete the achievement tests as well as the CRS in a detailed way. The students were asked to respond on CRS within the shortest time possible.

3. During the treatment phase of the study in relation to explicit teaching and implicit learning, the researcher made use of booklets for presentations and worksheets for exercises, both of which were developed by the researcher herself. The worksheets and booklets were copied according to the number of the participants in the experimental group. The participants used the same booklets throughout the study. The researcher took back the booklets when the lesson was over and brought them back in the following lesson.

4. After the administration of the pre-tests, the participants in the first experimental group were provided with explicit teaching on concept and generalization structure. Neither the second experimental group nor the control groups were provided any treatments at this phase of the study. The first experimental group students were given the booklets (written texts) regarding concept and generalization structure. The students were asked to write their names and surnames where indicated, and to review the booklets and up to the specified page number. Once the explicit teaching of the content components of the concept and generalization structure were completed through presentations and worksheets in the first experimental group, the participants were administered CGSSAT and CGSMCT as post-tests, with a view to identifying the effect of explicit teaching on learning. Behaviourist Theory in the Learning-Instruction Theories and Approaches course was chosen as the lesson content for implicit learning activities. Before the implicit learning activities, all the groups were given short-answer and multiple choice tests on behaviourist theory as pre-tests. Then, the first and second experimental groups were provided with implicit learning activities regarding behaviourist learning theory. The students used the booklets and worksheets which were prepared for implicit learning activities. While the implicit learning activities were conducted, the students were not given any explanations or terms that would highlight these content components. In the same vein, although the booklets presented information regarding the concepts and principles of behaviourist theory, no information was provided about the content components of concept and generalization.

5. All the conversations that took place in the experimental group classrooms were tape recorded. Besides this, all the teaching activities were observed by an instructor who is an expert in the field. Explicit teaching and implicit learning activities were conducted using lecture and question-answer 
techniques. The students were asked questions and provided feedback and revision with a view to increasing participation and preventing incorrect knowledge on the topic.

6. In the first experimental group, behaviourist learning theory was taught by their instructor who planned the learning content on her own. In the second experimental group, the instruction about the behaviourist learning theory was provided through students' presentations. The researcher did not interfere with the instructions and materials in the control groups, which were given only the pre and post-tests.

7. Once the instruction on behaviourist learning theory was completed in experimental and control groups, all the groups in the study were administered CGSSAT and CGSMCT as post-tests. Concept and generalization structure tests, and tests on behaviourist learning theory, were administered in two different lessons conducted within the same week. The students were given an hour for each test. Findings of the present study are limited to the data obtained only from CGSSAT and CGSMCT.

\section{Teaching Materials}

\section{Teaching materials prepared for explicit teaching}

Explicit teaching of concept and generalization structure was provided through the booklets, worksheets and presentation files. The booklet included concept schemas and maps. Firstly, content components of concept and generalization structure were analysed using various sources in order to prepare the teaching materials (Coşkun, 1999; Doğanay, 2003; Ehrenberg, 1991; Erickson, 1995; Gagne,Wager, Golas, \& Keller, 2005; Klausmeier, 1992; Merrill, 1983; Martorella, 1986, 1998; Marzano et al., 1988; Michaelis \& Garcia, 1996; Özlem, 1996, 2003, 2004; Tennyson \& Cocchiarella, 1986; Ströker, 2005; Sunal \& Sunal, 2003; Şimşek, 2006). Content components for which concept analyses were conducted include concept name, concept definition, critical attributes, variable attributes of the concept, concept hierarchy (superordinate-subordinate-coordinatie concepts), and examples and nonexamples of the concept. Content componets for which generalization analysis was conducted include generalization name, statement of generalization as proposition, concepts in proposition, and interrelationships among the concepts (causal relationships), and examples and non-examples of the generalization. The content components were exemplified using "Lake and mammal" concepts at the presentation stage and "citizen and equilateral triangle" concepts at the practice stage.

To exemplify the content components of generalization, "expansion law: all materials expand when they get warm enough" and "the number of babies that mammals give birth to affects the number and status of milk glands" generalizations were used at the presentation stage; "individuals have rights and responsibilities as citizens of the country they live in" and "people who live in places with limited sources of income migrate to places with higher sources of income" generalizations were used at the practice stage. Concepts and generalizations used at the presentation and practice stages were analysed in terms of their content components. The analyses were revised by the help of experts in the domain. Concept and generalization analyses were revised in light of the feedback and recommendations given by the experts.

\section{Teaching materials prepared for implicit learning}

Booklets, worksheets and presentation files were prepared for carrying out implicit learning activities. Teaching materials were prepared in light of the various sources on concepts and principles of behaviourist learning theory (Domjan, 2004; Driscoll, 2005; Frieman, 2002; Gould \& Gould, 2005; Ormrod, 2008; Senemoğlu, 2007). The terms taught in the scope of behaviourist learning theory include conditioning, classical conditioning, operant conditioning, reinforcement, positive reinforcement, negative reinforcement, and punishment. The principles taught on the same topic are contiguity, stimulus generalization, discrimination, extinction and spontaneous recovery. The concepts and principles indicated in the booklets which were prepared for implicit learning activities were given without highlighting the content components of concept and generalization structure. For instance, no 
explanations were provided about "critical attributes of the concept", "fundamental features", "variable attributes", or "changing features". The same order of the content components of concept and generalization was followed with a view to enabling the participants to be exposed to the recurrent pattern which is present in the booklet. In this way, the researcher aimed to help learners guess the concept and generalization structures by exposing them to orders and patterns that were recurrent in the teaching material (Frick \& Lee, 1995; Gasparini, 2004; Reber, 1993).

\section{Data Analysis}

The data were analysed using SPSS 11.5 package programming. Three different measurements were obtained in the testing phase of the study. The first one is the total achievement scores the students got from each test; the second one is the confidence rating mean difference scores; and the third one is the mean score of correct response confidence rating for each question. Mean difference scores for confidence rating were calculated by subtracting the students' incorrect response confidence rating means from correct response confidence rating means. Because the participants indicated high confidence rating scores not only for correct responses but also for incorrect ones, confidence rating mean score differences took both negative and positive values.

Whether there is a significant difference between the pre-test total scores, confidence rating mean differences, and correct response confidence rating mean scores were tested using one way variance analysis. Descriptive analyses of the data were performed via means, standard deviations and adjusted means. Normality premise was analysed through Kolmogorov-Smirnov test and histogram graph, which indicated normal distribution. Covariance analysis (ANCOVA) was used with a view to identifying any significant differences between the experimental and control groups in terms of their post-test total achievement scores, confidence rating mean difference scores, and correct response confidence rating mean scores. The analyses were conducted after confirming that intra-group regression coefficient-the fundamental premise for covariance analysis meets the premise of equivalence (equivalence of regression coefficients) (Büyüköztürk, 1998, 2001). Bonferroni test was used when the common effect was found to be significant in the covariance analysis results. Significance level was taken as .05 in the analyses.

\section{Results}

This section presents the findings resulting from the statistical analyses conducted for the subobjectives of the study

\section{Results regarding the First Sub-objective of the Study}

Table 4 presents findings regarding the experimental and control groups' means, standard deviations, adjusted means, covariance analysis, and Bonferroni test results for CGSSAT pre and posttest total achievement scores.

As seen in Table 4, mean scores for pre-test total achievement are $(\bar{X}=4.96)$ in the first experimental group, $(\bar{X}=6.20)$ in the second experimental group, $(\bar{X}=4.35)$ in the first control group, and $(\bar{X}=3.71)$ in the second control group. Mean scores for the post-test total achievement are $(\bar{X}=$ $30.25)$ in the first experimental group, $(\bar{X}=16.76)$ in the second experimental group, $(\bar{X}=11.74)$ in the first control group, and $(\bar{X}=9.86)$ in the second control group. Covariance analysis performed with a view to identifying whether this difference between the groups is significant shows that when the CGSSAT pre-test total achievement scores were controlled, the main effect of the grouping was found to be significant in terms of post-test adjusted mean scores $F(3-92)=65.435, p<.001$. Bonferroni multiple comparison test results performed with a view to identifying in which groups the difference occurred show that there are significant differences between the first experimental group $\left(\bar{X}_{d}=30.21\right)$ and the 
second experimental group $\left(\overline{\mathrm{X}}_{\mathrm{d}}=15.53\right)$; and between the first control group $\left(\overline{\mathrm{X}}_{\mathrm{d}}=12.28\right)$ and the second control group $\left(\overline{\mathrm{X}}_{\mathrm{d}}=11.01\right)$, and between the second experimental group and the second control group. Bonferroni results indicate that the significant difference is in favour of the experimental groups.

Table 4.

Means, Standard Deviations, Adjusted Means, Covariance Analysis, and Bonferroni Test Results for CGSSAT Pre- and Post-test Total Achievement Scores in Experimental and Control Groups

\begin{tabular}{|c|c|c|c|c|c|c|c|}
\hline \multirow[t]{2}{*}{ Groups } & \multirow[t]{2}{*}{ Tests } & \multicolumn{3}{|c|}{ Total Achievement Scores } & \multirow[t]{2}{*}{$F$} & \multirow[t]{2}{*}{$p$} & \multirow{2}{*}{$\begin{array}{l}\text { Bonferroni } \\
\text { results }\end{array}$} \\
\hline & & $\overline{\mathrm{X}}$ & SS & $\begin{array}{l}\text { Adjusted } \\
\text { means }\end{array}$ & & & \\
\hline \multirow[t]{2}{*}{$\mathrm{E}-1(n: 24)$} & Pre-test & 4.96 & 2.87 & - & \multirow[t]{8}{*}{65.435} & \multirow[t]{8}{*}{.000} & $\mathrm{D}_{1}>\mathrm{D}_{2}, \mathrm{~K}_{1}, \mathrm{~K}_{2}$ \\
\hline & Post-test & 30.25 & 5.58 & 30.21 & & & $\mathrm{D}_{2}>\mathrm{K}_{2}$ \\
\hline \multirow[t]{2}{*}{$\mathrm{E}-2(n: 29)$} & Pre-test & 6.20 & 4.43 & - & & & \\
\hline & Post-test & 16.76 & 6.65 & 15.53 & & & \\
\hline \multirow[t]{2}{*}{ C-1 $(n: 23)$} & Pre-test & 4.35 & 2.33 & - & & & \\
\hline & Post-test & 11.74 & 6.22 & 12.28 & & & \\
\hline \multirow[t]{2}{*}{ C-2 $(n: 21)$} & Pre-test & 3.71 & 1.79 & - & & & \\
\hline & Post-test & 9.86 & 5.49 & 11.01 & & & \\
\hline
\end{tabular}

\section{Results regarding the Second Sub-objective of the Study}

Table 5 presents findings regarding the experimental and control groups' means, standard deviations, adjusted means, covariance analysis, and Bonferroni test results for CGSSAT pre- and posttest confidence rating mean difference scores.

Table 5.

Means, Standard Deviations, Adjusted Means, Covariance Analysis, and Bonferroni Test Results for CGSSAT Pre and Post-test Confidence Rating Mean Diffrence Scores in Experimental and Control Groups

\begin{tabular}{lllllll}
\hline Groups & Tests & \multicolumn{3}{c}{ Total Difference Scores } & $F$ & \multirow{2}{*}{$p$} \\
\cline { 2 - 5 } & & $\overline{\mathrm{X}}$ & $\mathrm{SS}$ & \multicolumn{1}{c}{ Adjusted Means } & & \\
\hline $\mathrm{E}-1(n: 24)$ & Pre- test & 4.02 & 14.64 & - & 1.370 & .257 \\
& Post test & 8.79 & 18.54 & 8.76 & & \\
$\mathrm{E}-2(n: 29)$ & Pre- test & 4.13 & 12.39 & - & & \\
& Post test & 4.28 & 4.98 & 4.26 & \\
$\mathrm{C}-1(n: 23)$ & Pre- test & 2.82 & 13.44 & - & \\
& Post test & 4.24 & 4.61 & 4.19 & \\
$\mathrm{C}-2(n: 21)$ & Pre- test & 9.05 & 15.64 & - & \\
& Post test & 3.31 & 3.92 & 3.43 & \\
\end{tabular}

Table 5 shows that CGSSAT pre-test confidence rating mean difference scores are $(\bar{X}=4.02)$ in the first experimental group, $(\bar{X}=4.13)$ in the second experimental group, $(\bar{X}=2.82)$ in the first control group, and $(\bar{X}=9.05)$ in the second control group. Post-test confidence rating mean difference scores are $(\bar{X}=8.79)$ in the first experimental group, $(\bar{X}=4.28)$ in the second experimental group, $(\bar{X}=4.24)$ in the first control group, and $(\bar{X}=3.31)$ in the second control group. As seen in Table 5, high standard deviation scores result from the fact that confidence difference scores also took negative (-) values. Covariance analysis results conducted with a view to finding out whether the differences are significant show that when the CGSSAT pre-test confidence rating mean scores were controlled, the main effect of the grouping was not statistically significant in terms of post-test adjusted mean scores $F(3-92)=1.370$, p>. 05 . 
Table 6 presents means, standard deviations, adjusted means, covariance analysis and Bonferroni test results for CGSSAT pre and post-test correct response confidence rating mean scores.

Table 6.

Means, Standard Deviations, Adjusted Means, Covariance Analysis, and Bonferroni Test Results for CGSSAT Pre and Post-test Correct Response Confidence Rating Mean Scores in Experimental and Control Groups

\begin{tabular}{|c|c|c|c|c|c|c|c|}
\hline \multirow[t]{2}{*}{ Groups } & \multirow[t]{2}{*}{ Tests } & \multicolumn{3}{|c|}{ Total Score } & \multirow[t]{2}{*}{$F$} & \multirow[t]{2}{*}{$p$} & \multirow{2}{*}{$\begin{array}{l}\text { Bonferroni } \\
\text { results }\end{array}$} \\
\hline & & $\overline{\mathrm{X}}$ & SS & $\begin{array}{l}\text { Adjusted } \\
\text { means }\end{array}$ & & & \\
\hline \multirow[t]{2}{*}{$\mathrm{E}-1(n: 24)$} & Pre- test & 65.68 & 12.86 & - & \multirow[t]{8}{*}{41.790} & \multirow[t]{8}{*}{.000} & \multirow{8}{*}{$\begin{array}{ll}\mathrm{D}_{1}>\mathrm{D}_{2}, & \mathrm{~K}_{1}, \\
\mathrm{~K}_{2}\end{array}$} \\
\hline & Post- test & 90.20 & 6.87 & 90.57 & & & \\
\hline \multirow[t]{2}{*}{$\mathrm{E}-2(n: 29)$} & Pre- test & 63.10 & 10.18 & - & & & \\
\hline & Post- test & 67.47 & 11.15 & 68.99 & & & \\
\hline \multirow[t]{2}{*}{ C-1 $(n: 23)$} & Pre- test & 64.36 & 11.00 & - & & & \\
\hline & Post- test & 68.81 & 9.64 & 69.76 & & & \\
\hline \multirow[t]{2}{*}{ C-2 $(n: 21)$} & Pre- test & 74.48 & 9.96 & - & & & \\
\hline & Post- test & 68.82 & 11.04 & 65.25 & & & \\
\hline
\end{tabular}

As Table 6 presents, CGSSAT pre-test correct response confidence rating mean scores are $(\bar{X}=65.68)$ in the first experimental group, $(\bar{X}=63.10)$ in the second experimental group, $(\bar{X}=64.36)$ in the first control group, and $(\bar{X}=74.48)$ in the second control group. Mean scores for post-test correct response confidence rating are $(\bar{X}=90.20)$ in the first experimental group, $(\bar{X}=67.47)$ in the second experimental group, $(\bar{X}=68.81)$ in the first control group, and $(\bar{X}=68.82)$ in the second control group. Results of the covariance analysis performed with a view to identifying whether the difference is significant demonstrate that when CGSSAT pre-test correct response confidence rating mean scores were controlled, the main effect of the grouping was found to be significant in terms of the post-test adjusted mean scores $F(3-92)=41.790, p<.001$. The Bonferroni test conducted with a view to identifying in which groups the differences occurred shows that there are significant differences between the first experimental group $\left(\bar{X}_{d}=90.57\right)$ and second experimental group $\left(\bar{X}_{d}=68.99\right)$; and between the first control group $\left(\bar{X}_{d}=69.76\right)$ and the second control group $\left(\bar{X}_{d}=65.25\right)$. No significant difference was detected between the second experimental group and the control groups. According to the Bonferroni test results, the difference is in favour of the first experimental group.

\section{Results regarding the Third Sub-Objective of the Study}

Table 7 presents means, standard deviations, adjusted means, covariance analysis, and Bonferroni test results in relation to pre- and post-test total achievement mean scores for CGSMCT.

Table 7 demonstrates that mean scores for the CGSMCT pre-test are $(\bar{X}=15.46)$ in the first experimental group, $(\bar{X}=14.86)$ in the second experimental group, $(\bar{X}=13.87)$ in the first control group, and $(\bar{X}=12.52)$ in the second control group. Mean scores for post-test total achievement are $(\bar{X}=$ $26.46)$ in the first experimental group, $(\bar{X}=15.66)$ in the second experimental group, $(\bar{X}=15.95)$ in the first control group, and $(\bar{X}=14.38)$ in the second control group. Covariance analysis performed with a view to identifying whether the difference between the groups is significant shows that when the CGSMCT pre-test total achievement scores are controlled, the main effect of the grouping is significant in terms of the post-test adjusted mean scores $\mathrm{F}(3-92)=30.135, \mathrm{p}<.001$. The Bonferroni test results conducted with a view to identifying the groups in which the differences occur show that there are significant differences between the first experimental group $\left(\bar{X}_{d}=25.44\right)$ and the second experimental group $\left(\bar{X}_{d}=15.15\right)$, and between the first control group $\left(\bar{X}_{d}=16.30\right)$ and the second control group $(\bar{X}$ $d=15.87)$. The Bonferroni results show that the difference is in favour of the first experimental group. 
Table 7.

Means, Standard Deviations, Adjusted Means, Covariance Analysis, and Bonferroni Test Results for CGSMCT Pre and Post-test Total Achievement Scores in Experimental and Control Groups

\begin{tabular}{llllllll}
\hline Groups & Tests & \multicolumn{3}{c}{ Total Achievement Score } & $F$ & $p$ & $\begin{array}{l}\text { Bonferroni } \\
\text { results }\end{array}$ \\
\cline { 3 - 6 } & & $\overline{\mathrm{X}}$ & $\mathrm{SS}$ & $\begin{array}{l}\text { Adjuste } \\
\mathrm{d}\end{array}$ & & \\
means & & & \\
\hline $\mathrm{E}-1(n: 24)$ & Pre- test & 15.46 & 4.20 & - & 30.135 & .000 & $\mathrm{D}_{1}>\mathrm{D}_{2}-\mathrm{K}_{1}-\mathrm{K}_{2}$ \\
& Post- test & 26.46 & 5.40 & 25.44 & & \\
$\mathrm{E}-2(n: 29)$ & Pre- test & 14.86 & 4.30 & - & & \\
& Post- test & 15.66 & 5.80 & 15.15 & & \\
$\mathrm{C}-1(n: 23)$ & Pre- test & 13.87 & 4.25 & - & & \\
& Post- test & 15.95 & 5.30 & 16.30 & & \\
$\mathrm{C}-2(n: 21)$ & Pre- test & 12.52 & 3.96 & - & & \\
& Post- test & 14.38 & 5.80 & 15.87 & & & \\
\hline
\end{tabular}

\section{Results regarding the Fourth Sub-objective of the Study}

Table 8 presents means, standard deviations, adjusted means, covariance analysis and Bonferroni test results in relation to pre- and post-test confidence rating mean difference scores for CGSMCT.

Table 8.

Means, Standard Deviations, Adjusted Means, Covariance Analysis, and Bonferroni Test Results for CGSMCT Pre-and Post-test Confidence Rating Mean Diffrence Scores in Experimental and Control Groups

\begin{tabular}{|c|c|c|c|c|c|c|}
\hline \multirow[t]{2}{*}{ Groups } & \multirow[t]{2}{*}{ Tests } & \multicolumn{3}{|c|}{ Total Difference Scores } & \multirow[t]{2}{*}{$F$} & \multirow[t]{2}{*}{$p$} \\
\hline & & $\overline{\mathrm{X}}$ & SS & Adjusted means & & \\
\hline \multirow[t]{2}{*}{$\mathrm{E}-1(n: 24)$} & Pre- test & 5.13 & 5.90 & - & 0.804 & .495 \\
\hline & Post- test & 3.07 & 3.95 & 2.71 & & \\
\hline \multirow[t]{2}{*}{$\mathrm{E}-2(n: 29)$} & Pre- test & 2.91 & 6.39 & - & & \\
\hline & Post- test & 4.56 & 6.79 & 4.71 & & \\
\hline \multirow[t]{2}{*}{ C-1 ( $n: 23)$} & Pre- test & 3.34 & 5.42 & - & & \\
\hline & Post- test & 3.31 & 3.43 & 3.37 & & \\
\hline \multirow[t]{2}{*}{$\mathrm{C}-2(n: 21)$} & Pre- test & 2.94 & 4.94 & - & & \\
\hline & Post- test & 4.05 & 4.97 & 4.19 & & \\
\hline
\end{tabular}

Table 8 shows that the mean difference scores of CGSMCT pre-test confidence rating are $(\bar{X}=5.13)$ in the first experimental group, $(\bar{X}=2.91)$ in the second experimental group, $(\bar{X}=3.34)$ in the first control group, and $(\bar{X}=2.94)$ in the second control group. Mean scores of the post-test confidence rating mean difference scores are $(\bar{X}=3.07)$ in the first experimental group, $(\bar{X}=4.56)$ in the second experimental group, $(\bar{X}=3.31)$ in the first control group, and $(\bar{X}=4.05)$ in the second control group. Covariance analysis which aimed to find out whether this difference is significant shows that when the CGSMCT pre-test confidence rating is controlled, the main effect of the grouping is not significant in terms of the post-test adjusted mean scores $(F(3-92)=0.804, p>.05)$.

Table 9 presents means, standard deviations, adjusted means, covariance analysis and Bonferroni test results in relation to pre- and post-test confidence rating mean scores for CGSMCT. 
Table 9.

Means, Standard Deviations, Adjusted Means, Covariance Analysis, and Bonferroni Test Results for CGSMCT Pre- and Post-test Correct Response Confidence Rating Mean Scores in Experimental and Control Groups.

\begin{tabular}{|c|c|c|c|c|c|c|c|}
\hline \multirow[t]{2}{*}{ Groups } & \multirow[t]{2}{*}{ Tests } & \multicolumn{3}{|c|}{ Total Score } & \multirow[t]{2}{*}{$F$} & \multirow[t]{2}{*}{$p$} & \multirow{2}{*}{$\begin{array}{l}\text { Bonferroni } \\
\text { results }\end{array}$} \\
\hline & & $\overline{\mathrm{X}}$ & SS & $\begin{array}{l}\text { Adjuste } \\
\mathrm{d} \\
\text { means }\end{array}$ & & & \\
\hline \multirow[t]{2}{*}{$\mathrm{E}-1(n: 24)$} & Pre- test & 80.96 & 6.85 & - & 16.629 & .000 & $D_{1}>D_{2}-K_{1}-K_{2}$ \\
\hline & Post- test & 92.24 & 5.94 & 90.49 & & & \\
\hline \multirow[t]{2}{*}{$\mathrm{E}-2(n: 29)$} & Pre- test & 75.75 & 9.86 & - & & & \\
\hline & Post- test & 73.52 & 11.94 & 74.55 & & & \\
\hline \multirow[t]{2}{*}{ C-1 (n:23) } & Pre- test & 77.75 & 9.29 & - & & & \\
\hline & Post- test & 76.32 & 10.47 & 76.29 & & & \\
\hline \multirow[t]{2}{*}{ C-2 $(n: 21)$} & Pre- test & 76.55 & 12.33 & - & & & \\
\hline & Post- test & 77.32 & 10.46 & 77.93 & & & \\
\hline
\end{tabular}

As seen in Table 9, mean scores of the pre-test correct response confidence rating for CGSMCT are ( $\bar{X}=80.96)$ in the first experimental group, $(\bar{X}=75.75)$ in the second experimental group, $(\bar{X}=77.75)$ in the first control group, $(\bar{X}=76.55)$ in the second control group. Mean scores of the post-test correct response confidence rating are $(\bar{X}=92.24)$ in the first experimental group, $(\bar{X}=73.52)$ in the second experimental group, $(\bar{X}=76.32)$ in the first control group, and $(\bar{X}=77.32)$ in the second control group. Covariance analysis results conducted with a view to finding out whether the difference is significant show that when the CGSMCT pre-test correct response confidence level mean scores were controlled, the main effect of the grouping was significant in terms of the post-test total adjusted means $F(3-92)=$ $16.629, p<.001$. The Bonferroni test which aims to find out in which groups the differences occurred shows that there are significant differences between the first experimental group $\left(\bar{X}_{d}=90.49\right)$ and the second experimental group $\left(\bar{X}_{d}=74.55\right)$, and between the first control group $\left(\bar{X}_{d}=76.29\right)$ and the second control group $\left(\bar{X}_{d}=77.93\right)$. Bonferroni test results show that the significant difference is in favour of the first experimental group.

\section{Discussion, Conclusion and Recommendations}

Findings obtained from the CGSSAT and CGSMCT achievement tests and the CRS are discussed below. According to the findings obtained from the CGSSAT post-test total achievement scores, there are significant differences between the first and second experimental groups in favour of the first experimental group; and between the second experimental and second control groups in favour of the second experimental group. As for the CGSSAT post-test confidence rating mean difference scores, no statistically significant differences were found between the experimental and control groups. However, when the pre-test correct response confidence rating mean scores of the groups are controlled, posttest correct response confidence rating mean scores indicate significant differences in favour of the first experimental group, in comparison to the second experimental and control groups.

According to the findings obtained from the experimental and control group students' CGSMCT posttest total achievement scores, there is a significant difference between the first experimental and second experimental group and the control groups in favour of the first experimental group. No significant differences were detected between the second experimental group and the control groups. In addition, no significant differences were detected between the experimental and control groups in terms of CGSMCT post-test confidence rating mean difference scores. However, CGSMCT post-test correct response confidence rating mean scores indicate significant differences in favour of the first 
experimental group, in comparison to the second experimental and control groups. No significant differences were found between the second experimental group and control groups.

To summarize the findings of the study, explicit teaching conducted in the first experimental group seems to be successful and effective in the acquisition of explicit knowledge, increasing the perceived confidence rating about the accuracy of the responses, namely awareness of what has been learned, and providing successful learning. The findings of the present study correspond to the findings in related literature relating to the effects of explicit teaching (McCleery, 2000; McCleery \& Tindal, 1999; Nokes \& Ohlsson, 2001; Özcan-Bayram, 2009; Robinson, 1997; Sætrevik et al, 2006; Zohar \& David, 2008). McCleery and Tindal (1999), point out that when compared to the constructive approach, concept anchoring for explicit teaching was found to be more effective in teaching the scientific method to students in risk groups and with learning difficulties. In a similar vein, Klahr and Nigam (2004) found that students in an explicit teaching group demonstrated more effective learning and made richer scientific judgements. Studies carried out by Dean and Kuhn (2007), and Zohar and David (2008) also found explicit teaching more effective than exploratory learning.

Concept and generalization structure can be considered a relatively more abstract, complex, and difficult subject in nature. According to the post-test results in relation to concept and generalization structure, explicit teaching seems to be effective in the acquisition of explicit knowledge. It also seems that students have noticed the content components that form concept and generalization structure by the help of explicit teaching, which indicates the effectiveness of the type of teaching provided. However, it is important to note that in order for any information to be usable in a specific content, students should be exposed to many correct examples and to frequently have applied the practices. For instance, although individuals are taught about critical thinking, problem solving, decision making and the stages of these skills, they cannot think critically, solve problems, or make correct decisions. In order for individuals to be able to do all these, they should be exposed to and interact with many correct examples. Based on this notion, more specific studies are recommended with a view to identifying which types of examples and how much practice is needed for which specific types of teaching content. On the other hand, implicit learning seems to have very little effect on the acquisition of concept and generalization structure. The finding indicates that although the awareness of the students in the implicit learning group regarding the accuracy of their knowledge on concept and generalization structure was low, there was a slight increase in their performance, which indicates that the experimental treatment conducted for implicit learning was partially effective.

Along with these findings, Ziori and Dienes (2008) point out that the existence of implicit learning cannot be ignored in the same experimental condition where there is explicit learning, similarly the existence of explicit learning cannot be ignored in an experimental condition where there is implicit learning. To Polanyi (1969, p.144), there is no totally explicit knowledge; all written and spoken words are meaningless when they lack implicit interactions. Thus, all knowledge is mainly implicit, and explicit knowledge is based on knowledge that is comprehended and implemented implicitly (in Neuweg, 2004). Therefore, a learning activity may contain the attainment of both implicit and explicit knowledge. Explicit knowledge may turn into implicit knowledge; and implicit knowledge may become explicit knowledge in time (Tee, 2005). Teaching scientific knowledge can start with explicit knowledge. Attainment of correct explicit knowledge facilitates attainment of correct implicit knowledge, which is obtained mostly through examples and practice. However, students may not always encounter correct examples. In this case, it is the correct explicit knowledge that guides students and makes them monitor their knowledge deliberatively.

In conclusion, this study has investigated the role of direct teaching and implicit learning of concept and generalization structure in the acquisition of explicit knowledge. The effect of these two approaches can be investigated in different course contents containing complex patterns. The present study was conducted in real classroom environments, using written texts and worksheets. Future studies many 
investigate the effects of written texts and computer- based simulation programs used in technologysupported classroom environments on explicit and implicit learning.

\section{References}

Amado, S. (1996). Farklı dikkat düzeylerinin örtük ve açık bellek üzerindeki etkileri.[The effects of different levels of attention on implicit and explicit memory]. Unpublished doctoral dissertation, Ege University, İzmir.

Antony, S., \& Santhanam, R. (2007). Could the use of a knowledge-based system lead to implicit learning. Decision Support Systems, 43, 141-151.

Berry, D. C., \& Broadbent, D. E. (1988). Interactive task and the implicit-explicit distinction. British Journal of Psychology, 79, 251-272.

Büyüköztürk, Ş. (1998). Kovaryans analizi (varyans analizi ile karşılaştırmalı bir inceleme. Ankara Üniversitesi Eğitim Bilimleri Fakültesi Dergisi, 31(1), 91-105.

Büyüköztürk, Ş. (2001). Deneysel desenler (1st ed.). Ankara: Pegema Yayınları.

Carnine, D. (1994). Introduction to the mini-series: Diverse learners and prevailing, emerging, and research-based educational approaches and their tools. School Psychology Review, 23(3), 341-350.

Clariana, R. B. (2003). The effectiveness of constructed-response and multiple-choice study tasks in computer aided learning. Journal of Educational Computing Research, 28(4), 395-406.

Clariana, R. B., \& Lee, D. (2001). The effects of recognition and recall study tasks with feedback in a computer based vocabulary lesson. Educational Technology Research and Development, 49(3), 2336.

Cleeremans, A., Destrebecqz, A., \& Boyer, M. (1998). Implicit learning: News from the front. Trends in Cognitive Sciences, 2(10), 406-415.

Cohen, L., Manion, L., \& Morrison, K. (2007). Research methods in education (6th ed.). New York: Routledge.

Coşkun, M. (1999). Ögeleri belirleme kuramına dayalı kavram öğretiminin akademik başarı ve kalıcılığa etkisi. [The effect of concept teaching based on component display theory on academic achievement and retention of learning]. Unpublished doctoral dissertation, Çukurova University, Adana.

Davou, M. (2002). Unconscious processes influencing learning. Pyschodynamic Practice, 8(3), 277-294.

Dean, D., \& Kuhn, D. (2007). Direct instruction vs. discovery: The long view. Science Education, 91, 384397.

Debbağ-Ergin, D. (2008). Ingilizcenin yabancı dil olarak öğretimi bağlamında ortaöğretim 10. sınıf öğrencilerinin rastlantısal ve öğretim yoluyla sözcük öğrenme süreçlerine ilişkin bir uygulama. [A case study on incidental and instructional vocabulary learning of 10th grade EFL learners]. Unpublished master's thesis, Ankara Üniversitesi, Ankara.

Destrebecqz, A., \& Peigneux, P. (2005). Methods for studying unconscious learning. In S. Laureys (Ed.), the boundaries of consciousness: Neurobiology and neuropathology. Progress in brain research, (pp.69-80). France.

Dienes, Z., \& Altmann, G. (1997). Transfer of implicit knowledge across domains: How implicit and how abstract? In D. Berry (Ed.), how implicit is implicit learning? (pp. 107-123). Oxford: Oxford University Press.

Doğanay, A. (2003). Öğretimde kavram ve genellemelerin geliştirilmesi, (2nd ed.). In C. Öztürk \& D. Dilek (Eds.), Hayat bilgisi ve sosyal bilgiler öğretimi (pp.227-225). Ankara: Pegema Yayınları. 
Mükerrem AKBULUT TAŞ \& Mahinur KARATAŞ COŞKUN - Çukurova University Faculty of Education Journal, 43(1), 2014, 19-38

Domjan, M. (2004). Koşullama ve öğrenmenin temelleri (1st ed.). (H. Çetinkaya, Çev.) Ankara: Türk Psikologlar Derneği Yayınları no:28.

Driscoll, M. P. (2005). Psychology of learning for instruction (3th ed.). Boston: Pearson Education, Allyn \&Bacon.

Eggen, P. D., \& Kauchak, D. P. (2007). Learning and teaching research-based methods (5th ed.). Boston: Pearson Education, Allyn \&Bacon.

Ehrenberg, S. S. (1991). Concept development (Rev. ed.). In A. Costa (Ed.), Developing minds. Alexandria, VA: ASCD.

Ellis, R. (2005). Measuring implicit and explicit knowledge of a second language: A psychometric study. Studies in Second Language Acquisition, 27, 141-172.

Erickson, H. L. (1995). Stirring the head, heart and soul: Redefining curriculum and instruction. California: Corwin Press.

Frensch, P. A. (1998). One concept multiple meanings. In M. A. Stadler, \& P. A. Frensch (Eds.), Handbook of implicit learning, (pp. 47-104). Thousand Oaks, CA: Sage Publications.

Frick, R.W., \& Lee, Y. S. (1995). Implicit learning and concept learning. The Quarterly Journal of Experimental Psychology Section A: Human Experimental Psychology, 48(3), 762-782.

Frieman, J. (2002). Learning and adaptive behavior. Wadsworth: Thomson Learning.

Gagne, R. M., Wager, W.W., Golas, K.C., \& Keller, J.M. (2005). Principles of instructional design (5th ed.). Wadsworth: Thomson Learning.

Gasparini, S. (2004). Implicit versus explicit learning: Some implications for 12 teaching. European Journal of Psychology of Education, 19 (2), 203-219.

Gould, J.L., \& Gould, C.G. (2005). Hayvan zihni (4th ed.). (D. Yurtören, Trans.). Ankara: Tübitak Yayınları, 142.

Hovardaoğlu, S. (2007). Davranış bilimleri için araştırma teknikleri (2nd ed.). Ankara: Hatiboğlu Yayınları.

Kang, S. H. K., McDermott, K.B., \& Roediger, H. L. (2007). Test format and corrective feedback modify the effect of testing on long-term retention. European Journal of Cognitive Psychology,19(4), 528558.

Karadağlı, i. (2009). The impact of the task-based instruction on the students' vocabulary learning in an English as a Foreign Language context. [Görev temelli öğretim yönteminin İngilizceyi yabancı dil olarak öğrenen öğrencilerin sözcük öğrenimine etkisi. Unpublished master's thesis, Marmara University, İstanbul.

Karasar, N. (1995). Bilimsel araştırma yöntemi (7th ed.). Ankara: 3A Araştırma Eğitim Danışmanlık.

Kirkhart, M. W. (2001). The nature of declarative and nondeclarative knowledge for implicit and explicit learning. The Journal of General Psychology, 128(4), 447-461.

Klahr, D., \& Nigam, M. (2004). The equivalence of learning paths in early science instruction; effects of direct instruction and discovery learning. Psychological Science, 15, 661-667.

Klausmeier, H. J. (1992). Concept learning and concept teaching. Educational Psychologist, 27(3), 267286.

Magliaro, S. G., Lockee, B. B., \& Burton, J. K. (2005). Direct instruction revisited: A key model for instructional technology. ETR\&D, 53(4), 41-55.

Martorella, P. H. (1986). Teaching concepts (3rd ed.). In J. M. Cooper (Ed.), Classroom teaching skill (pp.182-223). Lexington, Mass: D.C. Health \& Co. 
Martorella, P. H. (1998). Social studies for elementary school children developing young citizens (2nd ed.).Upper Saddle River, NJ: Prentice-Hall.

Marzano, R.J., Brandt, R.S., Hughes, C.S., Jones, B.F., Presseisen, B.Z., Rankin, S.C., \& Suhor, C. (1988). Dimensions of thinking: $A$ framework for curriculum and instruction. Alexandria, VA: ASCD.

Mathews, R.C., Buss, R.R., Chinn, R., \& Stanley, W. B. (1988). The role of explicit and implicit learning processes in concept discovery. The Quarterly Journal of Experimental Psychology Section A, 4O(1), 135-165.

Mathews, R. C., Buss, R. R., Stanley,W. B., Blanchard-Fields, F., Cho, J. R., \& Druhan, B. (1989). Role of implicit and explicit processes in learning from examples: A synergistic effect. Journal of Experimental Psychology: Learning, Memory, and Cognition. 15(6), 1083-1100.

Mathews, R.C., Roussel, L.G., Cochran, B.P., Cook, A. E., \& Dunaway, D. L. (2000). The role of implicit learning in the acquisition of generative knowledge. In V. Honavar, (Action Ed.). Journal of Cognitive Systems Research, 1, 161-174.

McCleery, J. A. (2000). Effects of explicit instruction and concept focus on student declarative content knowledge and problem solving skills. Dissertation Abstracts International, 61(09), 137. (PQDT No: AAT 9987238).

McCleery, J.A., \& Tindal, G.A. (1999). Teaching the scientific method to at-risk students and students with learning disabilities through concept anchoring and explicit instruction. Remedial and Special Education, 20(1), 7-18.

Merrill, M. D. (1983). Component display theory. In C. M. Reigeluth (Ed.), Instructional design theories and models (pp. 279-330). Hillsdale, NJ: Lawrence Erlbaum.

Michaelis, J.U., \& Garcia, S. (1996). Social studies for children: A guide to basic instruction (11th ed.). Boston: Allyn \& Bacon.

Neuweg, G. H. (2004). Tacit knowing and implicit learning. In M. B. Fischer \& N. Nicholas (Eds.), European perspectives on learning at work: The acquisition of work process knowledge. Cedefob Reference Series Luxemburg: Office for Official Publications for the European Communities.

Nokes, T.J., \& Ohlsson, S. (2001). How is abstract generative knowledge acquired? In J. D. Moore \& K. Stenning (Eds.), Proceedings of the Twenty Third Annual Conference of the Cognitive Science Society (pp. 710-715). Mahaw, NJ: Erlbaum.

Ormrod, J.E. (2008). Human learning (5th ed.). Upper Saddle River, NJ: Merrill Prentice-Hall.

Overskeid, G. (1995). Cognitivist or behaviourist- who can tell the difference? The case of implicit and explicit knowledge. British Journal of Psychology, 86, 517-522.

Özcan-Bayram, D. (2009). A comparison of the effects of explicit and implicit vocabulary teaching on students' vocabulary learning and retention levels through reading texts. [Okuma parçaları ile bilinçli ve dolaylı kelime öğretiminin öğrencilerin kelime öğrenme ve öğrenmenin kalıcılığı üzerine etkilerinin karşılaştırılması]. Unpublished master's thesis, Muğla Üniversitesi, Muğla.

Özlem, D. (1996). Felsefe ve doğa bilimleri (2nd ed.). İstanbul: İnkılâp Yayınevi.

Özlem, D. (2003). Bilim felsefesi (ders notları). İstanbul: İnkılâp Yayınevi.

Özlem, D. (2004). Mantık (7th ed). İstanbul: İnkıâp Yayınevi.

Pacton, S., Perruchet, P., Fayol, M., \& Cleeremans, A. (2001). Implicit learning out of the lab: The case orthographic regularities. Journal of Experimental Pyschology: General, 130(3), 401-426.

Reber, A. S. (1993). Implicit learning and tacit knowledge. Oxford: Oxford University Press. 
Robinson, P. (1997). Generalizability and automaticity of second language learning under implicit, incidental, enhanced, and instructed conditions. Studies in Second Language Acquisition, 19(2), 223227.

Sætrevik, B., Reber, R., \& Sannum, P. (2006). The utility of implicit learning in the teaching of rules. Learning and Instruction, 16(4), 363-373.

Sandberg, K., Timmermans, B., Overgaard, M., \& Cleeremans, A. (2010). Measuring consciousness: Is one measure better than the other? Consciousness and Cognition. doi:10.1016/j.concog.2009.12.013.

Senemoğlu, N. (2007). Gelişim, öğrenme ve öğretim. Ankara: Gönül Yayıncılık.

Shanks, D. R. (2005). Implicit learning. In K. Lamberts, \& R. Goldstone (Eds.), handbook of cognition (pp. 202-220). London: Sage Publications.

Shanks, D. R., \& St. John, M. F. (1994). Characteristics of dissociable human learning systems. Behavioral and Brain Sciences. 17 (3), 367-447.

Ströker, E. (2005). Bilim kuramına giriş (D. Özlem, Çev.) İstanbul: İnkılâp Yayınevi.

Sunal, D.W., \& Sunal, C.S. (2003). Science in the elementary and middle school. Columbus, OH: Merrill Prentice Hall.

Şimşek, A. (2006). Kavramların öğretimi. In A. Şimşek (Ed.), İçerik türlerine dayalı öğretim (pp. 27-70). Ankara: Nobel Yayınları.

Tatar, A. (1998). Kısa süreli bellekte özenli tekrar sürecinin açık ve örtük belleğe etkisi. [Effects of short term rehearsal on explicit and implicit memories]. Unpublished master's thesis, Ege University, İzmir.

Tavat, B. (1991). Örtük ve açık yönerge, kodlama ve sunum türünün yeni çağrışımlar kurmaya etkisi. Unpublished master's thesis, Hacettepe University, Ankara.

Tee, M. Y. (2005). Sharing and cultivating tacit knowledge in an e-learning environment: A naturalistic study. Dissertation Abstracts International, 66(08), 223 (PQDT.No: 3185234).

Tennyson, R.D., \& Cocchiarella, M.J. (1986). An empirically based instructional design theory for teaching concepts. Review of Educational Research, 56(1), 40-71.

Türk, E. (2007). Effects of the presentation mode of multimedia annotations on 12 reading comprehension and incidental vocabulary learning. [Multimedya açıklayıcı notlarının sunu modunun ikinci dilde okuduğunu anlama ve rastlantısal kelime öğrenme üzerine etkileri]. Unpublished master's thesis, Boğaziçi University, İstanbul.

Ziori, E., \& Dienes, Z. (2006). Subjective measures of unconscious knowledge of concepts. Mind \& Society. 5, 105-122.

Ziori, E., \& Dienes, Z. (2008). How does prior knowledge affect implicit and explicit concept learning? The Quarterly Journal of Experimental Psychology, 61(4), 601-624.

Zohar, A., \& David, A.B. (2008). Explicit teaching of meta-strategic knowledge in authentic classroom situations. Metacognition and Learning, 3(1), 59-82. 